\title{
Adsorptive removal of mercury from water by adsorbents derived from date pits
}

\begin{abstract}
Mohammad A. Al-Ghouti $\mathbb{1}^{1 *}$, Dana Da'ana ${ }^{1}$, Mohammed Abu-Dieyeh ${ }^{1}$ \& Majeda Khraisheh ${ }^{2}$
The current work presented here focuses on the remediation of mercury from water using modified low-cost materials. Modified date pits, low cost, minimal pretreatment steps and locally abundant agricultural waste materials were effectively employed as an adsorbent for remediating $\mathrm{Hg}^{2+}$ from aqueous media. Physical and chemical modification were developed such as thermal roasting (RDP), sulfur (SMRDP) and silane (SIMRDP) based modifications. Results showed that maximum adsorption by $\mathrm{RDP}$ was at $\mathrm{pH}$ 6, $\mathrm{AC}$ and both modifications was at $\mathrm{pH}$ 4. Furthermore, RDP has exothermic adsorption mechanism while AC, SMRDP, and SIMRDP have endothermic. All adsorbents except SIMRDP have spontaneous adsorption process. SEM analysis showed that the surface morphology of RDP was not significantly affected by different treatments while surface of $A C$ was affected. The investigation for good adsorbents for $\mathrm{Hg}^{2+}$ uptake from different anthropogenic sources has been carried out by many investigators worldwide towards having a safe environment. In the current study, the highest $\mathrm{Hg}^{2+}$ adsorption of SMRDP was relatively high compared to other known adsorbents.
\end{abstract}

Mercury abatement from aqueous medium is a serious environmental management endeavor due to the pernicious effects of either long - term or short - term effects that is caused by mercury $(\mathrm{Hg})$ species on the human health as well as on the aquatic ecology $y^{1,2}$. Furthermore, the rapid industrial development around the world caused a critical environmental issue of mercury in water in which $\mathrm{Hg}$ (II) was ranked as the sixth toxic chemical in the hazardous compounds list, considering it as one of the most dangerous and ubiquitous heavy metals in aqueous environment ${ }^{1}$. Industries such as plastic industries, oil refineries, pulp industries, cement industry, and various other industries are also source of mercury in the environment ${ }^{3}$. In addition, mercury cells, and fluorescent lamps can also become source of mercury after usage.

Decontaminating or recovering mercury present in the glass, phosphor powder, and end caps of spent fluorescent lamps can become a source of mercury in the environment Mercury percentage recovery depends on the wet or dry treatment methods used. Sobral et al. ${ }^{4}$, removed $99 \%$ of mercury from spent fluorescent lamps by electroleaching process, while a combination of electrowinnig process led to the recovery of $81 \%$ of mercury . Moreover, $^{5}$ $95 \%$ of mercury was recovered by the combination of photocatalytic process with sodium hypochlorite extraction solution $^{6}$. Our previous research used microwave-assisted technique for leaching of mercury from fluorescent lamps for bioremediation and results showed mercury leaching efficiency of $76.4 \%{ }^{7}$.

Once released into the environment, natural biological and chemical processes will influence mercury species, which dictates its toxicity and bioavailability. Elemental mercury is the simplest form of mercury, which is very harmful to both human and environment, and it cannot be degraded or broken down into harmless substances. In addition, mercury has various states and species, which will vary during its biogeochemical cycle. Accumulation of mercury after its liberation from ores and fossil fuel could occur at the surface soil of the earth, water bodies and bottom sediments, and it will start cycling between earth's surface and the atmosphere when released to the biosphere ${ }^{8,9}$. Accordingly, safe disposal practices and the elimination and recovery of mercury is essential to avoid adverse impacts on humans and the environment ${ }^{10}$. Furthermore, nervous system, gastrointestinal and renal systems are adversely affected by the ingestion of mercury - contaminated water, in which mercury combines with the thiol residues present in the proteins of the human body and impairs the mental and neurological functions ${ }^{11}$. Thus, the maximum allowable concentration of $\mathrm{Hg}$ (II) ion by world health organization (WHO) in wastewater discharge and potable water is 5 and $1 \mu \mathrm{g} / \mathrm{L}$, respectively ${ }^{12}$.

${ }^{1}$ Department of Biological and Environmental Sciences, College of Arts and Sciences, Qatar University, P.O. Box: 2713, Doha, Qatar. ${ }^{2}$ Department of Chemical Engineering, College of Engineering, Qatar University, P.O. Box: 2713, Doha, Qatar. *email: mohammad.alghouti@qu.edu.qa 


\begin{tabular}{|l|l|l|}
\hline Removal technique & Advantages & Disadvantages \\
\hline Ion exchange & $\begin{array}{l}\text { Fast kinetics. } \\
\text { High capacity of treatment. } \\
\text { High removal efficiency. }\end{array}$ & $\begin{array}{l}\text { Resins synthetic is costly. } \\
\text { Serious secondary pollution is caused by regeneration of } \\
\text { the resins. } \\
\text { Waste products are produced } \\
\text { Selectivity is low. }\end{array}$ \\
\hline Adsorption & $\begin{array}{l}\text { Wide pH range. } \\
\text { Low cost. } \\
\text { Metal binding capacities are high. } \\
\text { Easy operation conditions. }\end{array}$ & $\begin{array}{l}\text { Waste products are produced. } \\
\text { Selectivity is low. }\end{array}$ \\
\hline Chemical precipitation & $\begin{array}{l}\text { Operation is simple. } \\
\text { Capital cost is low. }\end{array}$ & $\begin{array}{l}\text { Generation of sludge. } \\
\text { Sludge disposal needs extra operational costs }\end{array}$ \\
\hline Membrane filtration & $\begin{array}{l}\text { Separation selectivity is high. } \\
\text { Requires small space and low pressure. }\end{array}$ & $\begin{array}{l}\text { Membrane fouling is expensive. } \\
\text { Process is complex. } \\
\text { Permeate flux is low. }\end{array}$ \\
\hline Flotation & $\begin{array}{l}\text { High metal selectivity and removal efficiency. } \\
\text { More concentrated sludge is produced. }\end{array}$ & \begin{tabular}{l} 
High initial capital cost, maintenance, and operation cost. \\
\hline
\end{tabular}
\end{tabular}

Table 1. Advantages and disadvantages of mercury removal techniques ${ }^{8,9}$.

These industries used several different conventional methods for the removal of mercury from water such as ion exchange, membrane filtration and other methodologies. However, according to Awual ${ }^{13}$, these techniques are expensive due to the requirement of secondary treatment step and still they can only reduce the mercury levels to $\mu \mathrm{g} / \mathrm{L}$ range in water ${ }^{1,2}$. Advantages and disadvantages of other techniques for removal of mercury ions are shown in Table 1 . Removal of $\mathrm{Hg}(\mathrm{II})$ from water by adsorption has been touted as the most fitting and simple methodology among the other available treatment options and selecting an appropriate adsorbent that suits $\mathrm{Hg}$ (II) ions properties is indispensable to obtain the maximum capacity of the adsorption process.

The common draw back for most of the existing technologies is high operational and maintenance costs, in addition to the generation of toxic sludge, generation of effluents, chemical consumption, inability to reuse mercury, and the difficulty of the processes with multiple steps ${ }^{14}$. Accordingly, adsorption especially, using low-cost easy to prepare adsorbents, has been reported as a potential cost-effective technique for remediation of mercury in small concentrations in water. Adsorption technique has several advantages over other techniques including the design simplicity, ease of operation, and high removal efficiency, which could reach $90-99 \%$. One of the most commonly used adsorbents for removal of pollutants and treatment of wastewater is activated carbon. The limitation of the usage of activated carbon is its high cost that increases the need to find an alternative adsorbent to remove mercury from aqueous medium ${ }^{15}$. According to Arias et al. ${ }^{16}$, these used methods for the removal of mercury from aqueous medium requires either several steps for the synthesis of the adsorbent material or needs preliminary activation, which in turn leads to poor green technologies or costly technologies. Therefore, it is necessary to develop a new type of adsorbing materials that can overcome the weakness and handicaps associated with the present adsorbents for mercury removal from liquid solutions.

Date pits as an agricultural waste can be used as effective adsorbents due to their low cost compared to activated carbon and their adsorption potential for pollutants removal. It is noteworthy that date palm is of great importance in the Qatari and Middle Eastern community for its known association with the religion and cultural practices. The date pits are considered a waste with zero economic value (with potential disposable issues) and form around $15 \%$ of the weight of the date fruit ${ }^{17}$. Several recent studies highlighted the potential use of date pits in its raw or modified states for the remediation of various metals and pollutants from variety of sources ${ }^{18}$. Mohammadi et al. ${ }^{19}$, used date pits seeds for the removal of heavy metals including $\mathrm{Pb}, \mathrm{Cd}$, As, and $\mathrm{Hg}$ from Cyprinus carpio fish and results showed decreased concentrations of heavy metals inside the fish. Moreover, Al-Ghouti et al. ${ }^{17}$, investigated the use of roasted date pits for $\mathrm{Br}^{-}$removal from water and results illustrates a great adsorption potential of the adsorbent. However, to the best of our knowledge, there is no studies that were previously done on the application of date pits in the removal of mercury from aqueous medium.

The remediation capacity of roasted date pits (RDP) needs some chemical modifications to be more effective. These chemical modifications include sulfur-modified roasted date pits (SMRDP) and silane-modified roasted date pits (SIMRDP) ${ }^{17,20}$. Given the great abundance of date pits and its disposable issues in Qatar and many countries in the Arabian Peninsula, it is now a need to develop the potential of date pits in adsorption technique for treatment of water. Hence, the objectives of this paper are formulated as: (i) to modify and activate the roasted date pits to produce sulfur-modified roasted date pits (SMRDP) and silane-modified roasted date pits (SIMRDP); (ii) to characterize the newly produced adsorbents in terms of scanning electron microscopy (SEM), and Fourier transform Infra-red (FTIR) spectroscopy (iii) to apply the newly produced adsorbents for adsorption of mercury from water and investigate their adsorption isotherms, and adsorption mechanisms and pathways.

\section{Materials and Methods}

Adsorbent collection and preparation. Qatari date fruits, Phoenix dactylifera L. were obtained from local markets. The chemical composition of date pits on dry matter basis was cellulose: $21.2 \pm 0.1$, hemicelluloses: $28.1 \pm 0.1$; and lignin: $19.9 \pm 0.1 \% W t$. The hard pit was the only part used in the preparation of the adsorbents. In order to remove dirt and impurities from the date pits, they were rinsed several times with distilled water, and then excess water was removed by drying date pits for 2 hours in an oven at $65^{\circ} \mathrm{C}$. After that, the dried date pits were roasted at $130^{\circ} \mathrm{C}$ for 3 hours in an oven to produce the roasted date pits (RDP). RDP was crushed and grounded into powder form then transferred to coffee machine where it was grinded further to 
obtain particles size ranging from coarse particles to fine particles. One particle size range $(0.250 \mathrm{~mm}-0.125 \mathrm{~mm})$ was used throughout the experiments. Moreover, commercial activated carbon (AC) that is locally available was used as a reference material due to it is widely use in the remediation and removal applications of several different pollutants.

Preparation of modified RDP. Sulfur-modified roasted date pits (SMRDP). Forty grams of RDP were weighed and added to $300 \mathrm{~cm}^{3}$ of $2 \mathrm{M} \mathrm{NaOH}$. Then, the mixture was agitated in a shaker incubator for 4 hours at $30^{\circ} \mathrm{C}$ and $165 \mathrm{RPM}$. After that, $20 \mathrm{~cm}^{3}$ of carbon sulfide was added to the mixture and re-incubated for another 4 hours at same conditions. After that, the supernatant was washed with distilled water several times, decanted, and placed in the oven of $70^{\circ} \mathrm{C}$ for 24 hours.

Silane-modified roasted date pits (SIMRDP). A solution made of pre-hydrolyzed $1.5 \%$ Vol 3-mercaptopropyltriethoxy-silane was added to a medium of 50/50\% Vol ethanol/water with $\mathrm{pH}$ of 4.5 adjusted by $5 \%$ acetic acid. After that, $31 \mathrm{~g}$ of RDP was weighed and added to the solution. Then, the mixture was agitated for 3 hours in shaker incubator at $25^{\circ} \mathrm{C}$ and $165 \mathrm{RPM}$. After that, the modified RDP was washed with the same medium and placed in the oven at $60^{\circ} \mathrm{C}$.

Characterization of the adsorbents. In general, adsorbent characterization in any adsorption system provides the essential understanding of the involved process and the mechanisms governing it ${ }^{17}$. Therefore, characteristics of adsorbents' surface (AC, RDP, SMRDP and SIMRDP) were determined before and after the adsorption process. Fourier transform infrared (FTIR) spectra of the adsorbents were recorded using the FTIR Perkin Elmer Model 2000. The FTIR analysis was carried out to interpret the functional groups, which occurred in the adsorbents. The FTIR measurements were performed over $4000-400 \mathrm{~cm}^{-1}$. In addition, scanning electron microscopy (SEM) was also used to evaluate the surface morphology of the adsorbents using the JEOL model JSM-6390LV.

Batch adsorption of mercury. Several different remediation parameters were investigated such as $\mathrm{pH}(2$, $4,6,8$, and 10), initial concentration $\left(0.5-8.0 \mathrm{mg} / \mathrm{dm}^{3}\right)$, and temperature $\left(25,35\right.$ and $\left.45^{\circ} \mathrm{C}\right) . \mathrm{A} 0.05 \mathrm{~g}$ of the adsorbent (RDP, SMRDP or SIMRDP) and $50 \mathrm{~mL}$ of mercury chloride $\left(\mathrm{HgCl}_{2}\right)$ solution at different initial concentrations were placed in acidified glass bottle and were shaken at $165 \mathrm{rpm}$ using a temperature-controlled shaker for 48 hours. All the samples were filtered and the $\mathrm{Hg}^{2+}$ concentration was determined using the cold vapor atomic absorption spectrophotometer (CVAAS). The concentration of mercury was chosen based on the available mercury concentration in the spent fluorescent lamps ${ }^{16}$.

Thermodynamic studies of mercury adsorption. Thermodynamic studies of an adsorption process are very important to determine the spontaneity of the adsorption process. One fundamental criteria of spontaneity is Gibb's free energy change $\Delta \mathrm{G}^{\circ}$. At a given temperature, spontaneous reaction occurs if $\Delta \mathrm{G}^{\circ}$ has a negative value. Moreover, change in enthalpy $\Delta \mathrm{H}^{\circ}$ and change in entropy $\Delta \mathrm{S}^{\circ}$ are necessary thermodynamic parameters. According to Tran et al. ${ }^{21}$, thermodynamic parameters of $\Delta \mathrm{G}^{\circ}, \Delta \mathrm{H}^{\circ}$, and $\Delta \mathrm{S}^{\circ}$ were calculated from the following equations:

$$
\begin{gathered}
\Delta G^{\circ}=-\mathrm{RT} \ln \mathrm{K}_{\mathrm{a}} ; \\
\Delta G^{\circ}=\Delta H^{\circ}-T \Delta S^{\circ} ;
\end{gathered}
$$

Where $\mathrm{R}$ is the gas constant $(8.314 \mathrm{~J} / \mathrm{mol} \mathrm{K}), \mathrm{T}$ is the temperature in Kelvin $(\mathrm{K})$, and $\mathrm{K}_{\mathrm{a}}$ is the Langmuir constant.

Adsorption isotherm of mercury adsorption. The relationship between the equilibrium concentration and the equilibrium adsorption capacity at a constant temperature in an aqueous medium were described through the adsorption isotherms. Four isotherm models were used to determine the best-fit model of the adsorption process, in which the experimental equilibrium data were fitted to Langmuir, Freundlich, Dubinin-Radushkevich, and Temkin isotherm models ${ }^{22}$. The linear forms of the four adsorption isotherm models as well as their constants and adsorption parameters are shown in Table 2.

Statistical analysis. Due to the fact that the experimental design of the experiments was completely randomized design (CRD) and the experiments were factorial, analysis of variance (ANOVA) for two factors was used for the assessment of the relationship between the initial concentration and the temperature. On the other hand, studying the effect of $\mathrm{pH}$ on the adsorption capacity of $\mathrm{Hg}^{2+}$ ions was a single factor experiment in which the temperature and concentration were constant throughout the experiment, as a result, ANOVA for single factor was used.

\section{Results and Discussion}

Mechanism of adsorption. Several investigators identified $\mathrm{Hg}^{2+}$ interaction on the adsorbent surfaces through chemical interactions $\mathrm{s}^{20,23-26}$. This would include electrostatic, ion exchange interaction and/or complexation or through a hydrophobic process especially for HgO. It was shown that adsorbents with oxygen and sulfur functional groups were better in $\mathrm{Hg}^{2+}$ adsorption ${ }^{20}$. It can be perceived from the FTIR results that oxygen and sulfur functional groups in the date pits and its modified forms are available. This finding is consistent to the previous investigations which indicated the presence of oxygenated functional groups in the adsorbent promote better $\mathrm{Hg}^{2+}$ adsorption ${ }^{20,27}$. 


\begin{tabular}{|c|c|c|}
\hline Model & Equation & Parameters \\
\hline $\begin{array}{l}\text { Langmuir } \\
\text { adsorption } \\
\text { isotherm }\end{array}$ & $\frac{\mathrm{C}_{e}}{\mathrm{q}_{\mathrm{e}}}=\frac{1}{\mathrm{~b} \cdot \mathrm{Q}_{\mathrm{o}}}+\frac{\mathrm{C}_{e}}{\mathrm{Q}_{0}}$ & $\begin{array}{l}\mathrm{q}_{\mathrm{e}} \text { is the amount of adsorbate in the adsorbent at equilibrium }(\mathrm{mg} / \mathrm{g}), \mathrm{Q}_{0} \text { is the } \\
\text { maximum monolayer coverage capacities }(\mathrm{mg} / \mathrm{g}), b \text { is the Langmuir isotherm constant } \\
(\mathrm{L} / \mathrm{mg}) \text {, and } C_{\mathrm{e}} \text { is the equilibrium concentration }(\mathrm{mg} / \mathrm{L}) \text {. } \\
\text { From the Langmuir isotherm, favorability of mercury adsorption on the adsorbents was } \\
\text { tested as shown in equation, } \mathrm{R}_{\mathrm{L}}=\frac{1}{1+b(\mathrm{Ce})} \text { Where } \mathrm{R}_{\mathrm{L}} \text { describes the feasibility of adsorption } \\
\text { process. If } \mathrm{R}_{\mathrm{L}}>1 \text {, the adsorption process would be unfavorable; } \mathrm{R}_{\mathrm{L}}=0 \text { the adsorption } \\
\text { process will be irreversible, while } 0<\mathrm{R}_{\mathrm{L}}<1 \text { indicates the adsorption process is } \\
\text { energetically favorable. }\end{array}$ \\
\hline $\begin{array}{l}\text { Freundlich } \\
\text { adsorption } \\
\text { isotherm }\end{array}$ & $\log q_{e}=\log K_{F}+\frac{1}{n} \log C_{e}$ & $\begin{array}{l}\mathrm{q}_{e} \text { is the amount of adsorbate in the adsorbent at equilibrium }(\mathrm{mg} / \mathrm{g}), \mathrm{K}_{\mathrm{F}} \text { is the Freundlich } \\
\text { adsorption constant }(\mathrm{mg} / \mathrm{g})(\mathrm{L} / \mathrm{g})^{\mathrm{n}} \text {, and } \mathrm{C}_{\mathrm{e}} \text { is the equilibrium constant. The value of } \mathrm{n} \\
\text { indicates the type of isotherm. When } \frac{1}{\mathrm{n}} \text { is greater than zero }\left(0<\frac{1}{\mathrm{n}}<1\right) \text {, the adsorption is } \\
\text { favorable, when } \frac{1}{\mathrm{n}}=1 \text {, the adsorption is irreversible, and when } \frac{1}{\mathrm{n}}>1 \text { the adsorption is } \\
\text { unfavorable. }\end{array}$ \\
\hline $\begin{array}{l}\text { Dubinin- } \\
\text { Radushkevich } \\
\text { adsorption } \\
\text { isotherm }\end{array}$ & $\ln \mathrm{q}_{\mathrm{e}}=\ln \mathrm{q}_{\mathrm{s}}-\mathrm{k}_{\mathrm{ad}} \varepsilon^{2}$ & $\begin{array}{l}\mathrm{q}_{\mathrm{e}} \text { is the amount of adsorbate in the adsorbent at equilibrium }(\mathrm{mg} / \mathrm{g}), \mathrm{q}_{\mathrm{s}} \text { is the theoretical } \\
\text { isotherm saturation capacity }(\mathrm{mg} / \mathrm{g}) \text {, and } \mathrm{k}_{\mathrm{ad}} \varepsilon^{2} \text { is the Dubinin-Radushkevich isotherm } \\
\text { constant }\left(\mathrm{mol}^{2} / \mathrm{kj}^{2}\right) \text {. }\end{array}$ \\
\hline $\begin{array}{l}\text { Temkin } \\
\text { Adsorption } \\
\text { Isotherm }\end{array}$ & $\mathrm{q}_{\mathrm{e}}=\frac{\mathrm{RT}}{\mathrm{b}_{\mathrm{T}}} \ln \mathrm{A}_{\mathrm{T}}+\left(\frac{\mathrm{RT}}{\mathrm{b}_{\mathrm{T}}}\right) \ln \mathrm{C}_{\mathrm{e}}$ & $\begin{array}{l}\mathrm{q}_{\mathrm{e}} \text { is the amount of adsorbate in the adsorbent at equilibrium }(\mathrm{mg} / \mathrm{g}), \mathrm{R} \text { is the universal } \\
\text { gas constant }(8.314 \mathrm{~J} / \mathrm{mol} \mathrm{K}), \mathrm{T} \text { is the temperature }(\mathrm{K}), \mathrm{b}_{\mathrm{T}} \text { is the Temkin isotherm } \\
\text { constant, } \mathrm{A}_{\mathrm{T}} \text { is the Temkin isotherm equilibrium binding constant }(\mathrm{L} / \mathrm{g}) \text {, and } \mathrm{C}_{\mathrm{e}} \text { is the } \\
\text { equilibrium concentration }(\mathrm{mg} / \mathrm{L})\end{array}$ \\
\hline
\end{tabular}

Table 2. Various adsorption models used in the current study ${ }^{27}$.

Cellulose is the main composition of RDP with the empirical formula $\left(\mathrm{C}_{6} \mathrm{H}_{10} \mathrm{O}_{5}\right)_{\mathrm{n}}$. Furthermore, lignin is another component of raw date pits its approximate percentage is $11.0 \%$ dry weight, while on RDP it can be found at percentages in the range of 16.9 to $26.2 \%{ }^{6,17,28}$. To prepare the modified form with the carbon disulfide, the RDP is treated with aqueous $\mathrm{NaOH}$ to form "alkali cellulose," $\left[\mathrm{C}_{6} \mathrm{H}_{9} \mathrm{O}_{4}-\mathrm{ONa}\right]_{n}$. Then, the alkali cellulose is treated with carbon disulfide to form sodium cellulose xanthate (SMRDP) as shown in (3) and Fig. 1.

$$
\left[\mathrm{C}_{6} \mathrm{H}_{9} \mathrm{O}_{4}-\mathrm{ONa}\right]_{\mathrm{n}}+\mathrm{nCS}_{2} \rightarrow\left[\mathrm{C}_{6} \mathrm{H}_{9} \mathrm{O}_{4}-\mathrm{OCS}_{2} \mathrm{Na}\right]_{\mathrm{n}}
$$

According to the results obtained from the FTIR spectra (Fig. 2), it was noticed that the peak presents at the region of $3363 \mathrm{~cm}^{-1}$ was stronger and has the highest intensity in the $\mathrm{pH}$ value of 6 , making it one of the major functional groups responsible for the higher adsorption capacity ${ }^{26,29}$. Results showed that the best adsorption capacity for SMRDP was found to be at $\mathrm{pH} 4$. As shown in Fig. 2, the functional groups formed on the surface of SMRDP are one strong, broad peak at the region of $3362 \mathrm{~cm}^{-1}$ ascribing the presence of stretching vibrations of $\mathrm{OH}$. Another peak was found at $1635 \mathrm{~cm}^{-1}$, which indicates the $\mathrm{OH}$ bending of absorbed water. Peaks at $1370 \mathrm{~cm}^{-1}$ and $1011 \mathrm{~cm}^{-1}$ corresponds to the presence of alkanes (C-H rock) in-the-plane $\mathrm{CH}$ bending and strong $\mathrm{C}-\mathrm{C} \mathrm{C}-\mathrm{OH}, \mathrm{C}-\mathrm{H}$ ring and side group vibrations, respectively.

The SIMRDP has several different peaks, first peak was found at $3469 \mathrm{~cm}^{-1}$ region, which can be due to the presence of the $\mathrm{O}-\mathrm{H}$ stretching of the aromatic ring ${ }^{30}$. Another peak was found at $1646 \mathrm{~cm}^{-1}$ region includes an $-\mathrm{C}=\mathrm{C}$ - stretch corresponding to the alkenes. Multiple functional groups were identified in the fingerprint region of the SIMRDP, including in the region of $1096 \mathrm{~cm}^{-1}$ and $805 \mathrm{~cm}^{-1}$. Two peaks were observed determining the presence of Si-O-Si bond, another Si-OH and Si-O bands were found at $960 \mathrm{~cm}^{-1}$ and $470 \mathrm{~cm}^{-130}$. The main difference between the adsorbents is the decrease in the intensity of the band found in the $3362 \mathrm{~cm}^{-1}$ at the surface of SIMRDP and it was replaced with another band which is ascribing to the presence of aromatic ring.

According to Mohammed et al. ${ }^{29}$, the peaks observed at 2928 and $2851 \mathrm{~cm}^{-1}$ are alkanes groups due to the presence of asymmetric $\mathrm{C}-\mathrm{H}$ vibration stretch of $-\mathrm{CH}_{2}$ group from primary alcohol. Moreover, due to the existence of the acetyl and ester groups in the hemicellulose structure of RDP, the peak present at $1744 \mathrm{~cm}^{-1}$ can be assigned to the carbonyl $\mathrm{C}=\mathrm{O}$ bond and an $\mathrm{CH}_{3}$ bending absorption occurs at $1377 \mathrm{~cm}^{-1}$ corresponding to the absorption of alkanes. The presence of two peaks, asymmetric C-O-C stretch at the region of $1250 \mathrm{~cm}^{-1}$ and another symmetric stretch at $1040 \mathrm{~cm}^{-1}$ indicates the presence of alkyl ether group. Furthermore, at the region of $1149 \mathrm{~cm}^{-1}$ a peak that is not very sharp can be observed which indicates the presence of ester group ${ }^{31-33}$.

As shown in Fig. 2, after the modification of RDP by carbon disulfide under $\mathrm{pH} 4$ and different $\mathrm{Hg}^{2+}$ concentrations $\left(0.5\right.$ to $\left.8 \mathrm{mg} / \mathrm{dm}^{3}\right)$, several different changes on the functional groups present in the surface of the adsorbent were observed: the replacement of alkanes group at $2928 \mathrm{~cm}^{-1}$ and $2851 \mathrm{~cm}^{-1}$ with higher wavenumber $3364 \mathrm{~cm}^{-1}$ due to the electrostatic attraction between sulfur and the $-\mathrm{OH}$ group. Moreover, the carbonyl $(\mathrm{C}=\mathrm{O})$ bond at $1744 \mathrm{~cm}^{-1}$ and the peak at $1377 \mathrm{~cm}^{-1}$ were shifted to lower wavenumber $1660 \mathrm{~cm}^{-1}$ and $1368 \mathrm{~cm}^{-1}$ with less intensity and more broadness. Other changes were the shift of $1250 \mathrm{~cm}^{-1}$ to lower wavelength $1242 \mathrm{~cm}^{-1}$ for syringyl ring, higher shift of $1008 \mathrm{~cm}^{-1}$ to $1035 \mathrm{~cm}^{-1}$ region of C-O stretch. Few changes are distinguished in the spectrum of SMRDP, Fig. 2. The broad peak at $3338 \mathrm{~cm}^{-1}$ in the RDP shifts to $3390 \mathrm{~cm}^{-1}$ in the SMRDP indicate the hydroxyl groups have combined with $\mathrm{CS}_{2}$. The presence of sulfur groups in the SMRDP has been identified by the appearance of new peaks at 613,1014 and 1075 corresponding to $\gamma \mathrm{C}-\mathrm{S}, \gamma \mathrm{C}=\mathrm{S}$ and $\gamma \mathrm{S}-\mathrm{C}-\mathrm{S}$.

Figure 3 shows the representative diagram of chemical reaction between 3-mercaptopropyltrimethoxysilane and RDP. The reaction steps involved are as follows: (i) 3-mercaptopropyltrimethoxysilane undergoes hydrolysis to become silanols; (ii) silanol is physically adsorbed to hydroxyl group of RDP; (iii) condensation of silanol 


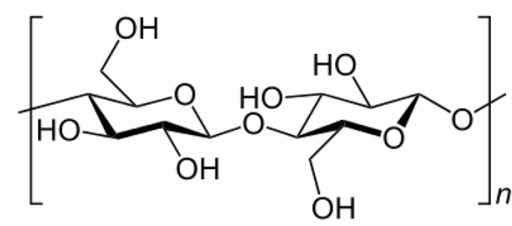

$+6 \mathrm{CS}_{2}$

$+6 \mathrm{NaOH} \downarrow-6 \mathrm{H}_{2} \mathrm{O}$

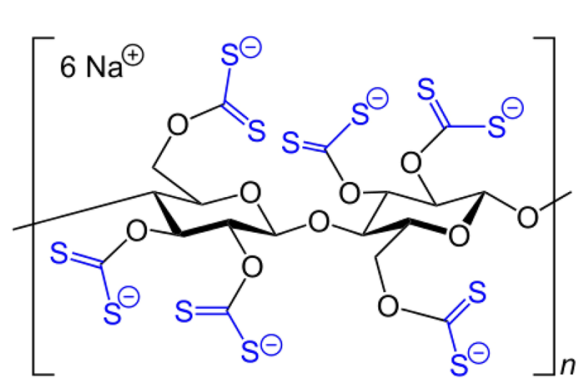

Figure 1. RDP treated with $\mathrm{CS}_{2}$.

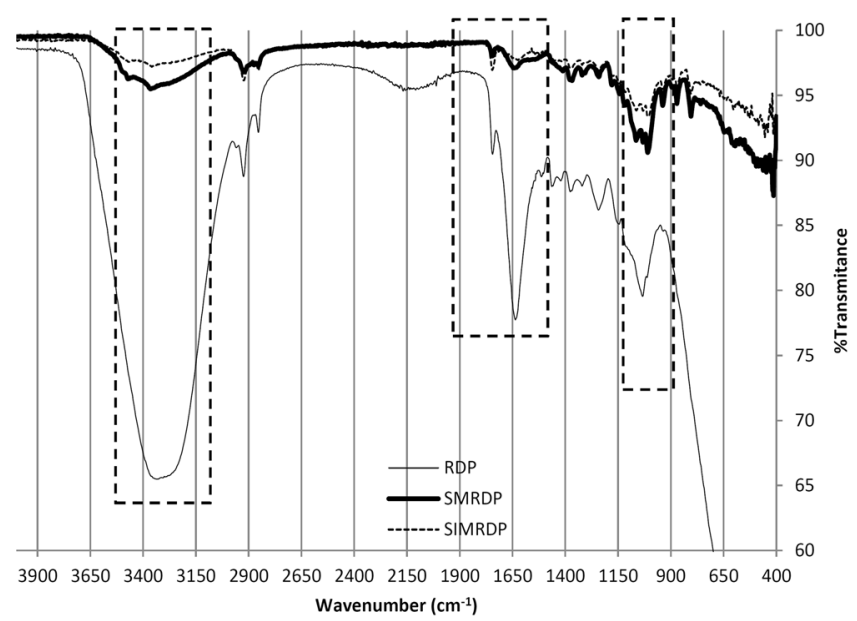

Figure 2. FTIR for the RDP, SMRDP, and SIMRDP.

and form Si-O-C bond between 3-mercaptopropyltrimethoxysilane and RDP. Furthermore, different changes were noticed at the surface SIMRDP which includes the formation of the alcohol functional group (-OH stretch) at $3365 \mathrm{~cm}^{-1}$, the $\mathrm{C}=\mathrm{O}$ stretch in $1744 \mathrm{~cm}^{-1}$ was shifted to higher wavelength at $1760 \mathrm{~cm}^{-1}$, but with reduced intensity. Multiple of bands were present in the region of $1000 \mathrm{~cm}^{-1}$ to $1320 \mathrm{~cm}^{-1}$ due to the presence of Si-O-C stretching ${ }^{34}$. Thiol groups were not clearly observed due to the low sensitivity of FTIR regarding the detection of this group. According to Song et al..$^{33}$, and Bobirica et al..$^{35}$, the success of grafting of 3-MPTS into the surface of the adsorbent was indicated by the presence of alkyl chain having C-H stretch of methylenes at $2925 \mathrm{~cm}^{-1}$ and $2850 \mathrm{~cm}^{-1}$ bands. The effect of temperature on the formation and presence of functional groups at the surface of RDP was also investigated (the figure is not shown here). The carboxylic functional group at $3300 \mathrm{~cm}^{-1}$ was absent at the higher concentrations of $\mathrm{Hg}^{2+}$. Almost same functional groups were found in the surface of RDP at temperature $25^{\circ} \mathrm{C}$ and $45^{\circ} \mathrm{C}$ with some differences in the intensity and broadness of the peaks. For example, a shift in the $\mathrm{CH}_{3}$ bending absorption at $1377 \mathrm{~cm}^{-1}$ corresponding to the absorption of alkanes was shifted to higher wavenumber $1381 \mathrm{~cm}^{-1}$. While the band at $1250 \mathrm{~cm}^{-1}$ was shifted to lower wavenumber $1238 \mathrm{~cm}^{-1}$ with lower intensity.

There is no difference in the functional groups found in the surface of SMRDP when the temperature increased up to $45^{\circ} \mathrm{C}$; however, the intensity and broadness of the bands were affected. On the other hand, the surface functional groups in SIMRDP showed a significance difference after increasing the temperature indicating the effect of temperature on the formation of different functional groups. 

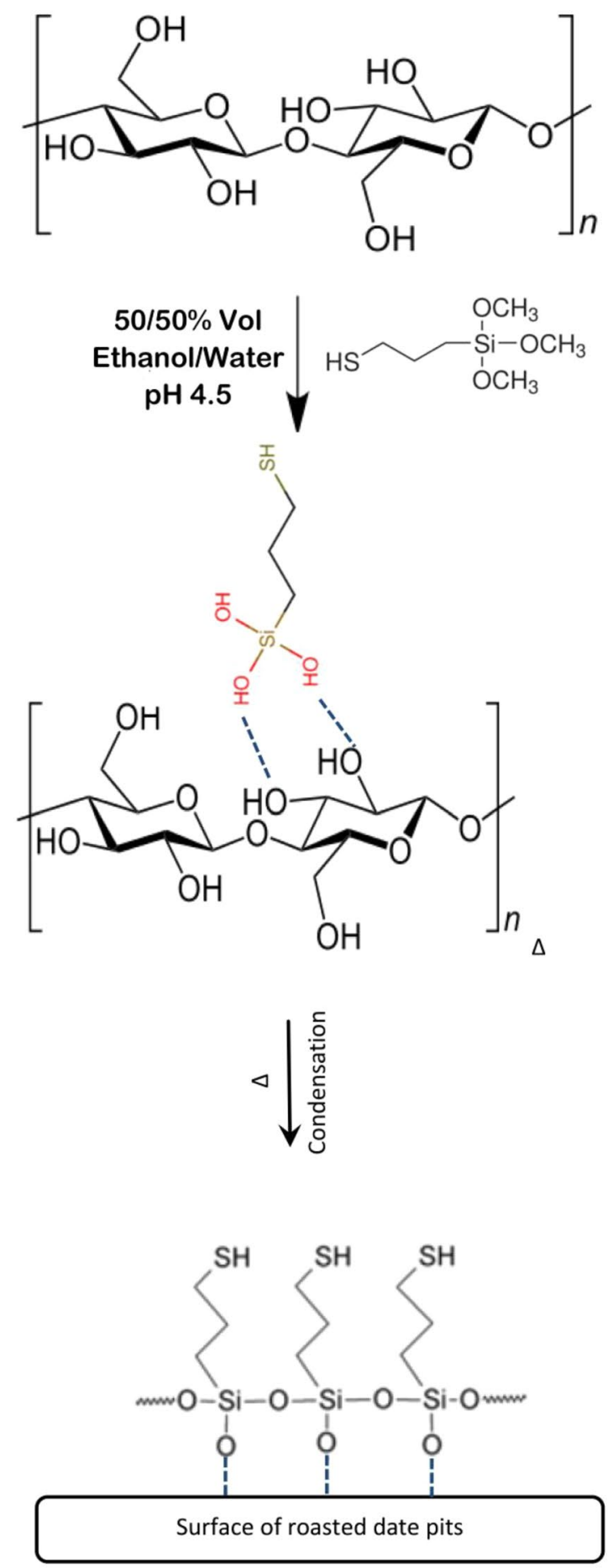

Figure 3. Representative diagram of chemical reaction between 3-mercaptopropyltrimethoxysilane and RDP.

Analysis of adsorbent's surface by scanning electron microscope (SEM). Surface morphology and physical properties of the adsorbent were investigated and determined by using SEM. Figure 4 shows the SEM of RDP before and after the treatment with different parameters including $\mathrm{pH}$, initial concentration, and temperature. From Fig. 4 it was observed that the structure of the adsorbent was changed upon adsorbing the $\mathrm{Hg}^{2+}$ ions, it was noticed that the change in the morphology of RDP in terms of the shape and size of the pores. The morphology before the effect of $\mathrm{pH}$ was irregular and smaller in size, while at $\mathrm{pH} 6$ they had more systematic shape and larger pore size. Moreover, after the increase of temperature from $25^{\circ} \mathrm{C}$ to $45^{\circ} \mathrm{C}$, no significant change in the surface morphology of RDP. However, when these results were compared with the SEM results of AC the differences in the morphological structure of both adsorbents were obvious. Surface of AC has network structure while after the treatment with different $\mathrm{Hg}^{2+}$ concentrations; it appeared in a more porous and defined structure. 
Effect of $\mathrm{pH}$ value on the $\mathrm{Hg}^{2+}$ adsorption. The effect of $\mathrm{pH}$ on the mercury adsorption efficiency onto $\mathrm{AC}, \mathrm{RDP}$ and its modifications were investigated and the results are shown in Fig. 5, illustrating the maximum percentage removal of $\mathrm{Hg}^{2+}$ was at $\mathrm{pH} 6$ for RDP, SMRDP, and SIMRDP, and $\mathrm{pH} 4$ for AC. It can be observed that the removal capacity of $\mathrm{Hg}^{2+}$ by RDP was slightly constant under acidic conditions (i.e. $\mathrm{pH} 2$ to 4 ), while the removal capacity of $\mathrm{Hg}^{2+}$ decreased from $97.5 \%$ to $91.9 \%$ when the $\mathrm{pH}$ was increased from 6 to 10 . However, the adsorption percentage of $\mathrm{Hg}^{2+}$ by AC increases at $\mathrm{pH} 4$ with removal percentage of $91 \%$ while with further increase in the $\mathrm{pH}$ value (above $\mathrm{pH}$ 4), the percentage removal of $\mathrm{Hg}^{2+}$ decreased to almost $78 \%$. An increase in the adsorption capacity of $\mathrm{Hg}^{2+}$ may result from the decreased electrostatic repulsion between the positively charged $\mathrm{Hg}^{2+}$ and the surface of RDP due to the decreased density of the surface charge when increasing the $\mathrm{pH}$ of the solution ${ }^{36} . \mathrm{Hg}^{2+}$ speciation within the solution is another aspect that should be considered for the analysis of $\mathrm{pH}$ effect on the adsorption of mercury. Zhang et al..$^{37}$, have shown that, when chelating agents are absent, $\mathrm{Hg}^{2+}$ and $\mathrm{Hg}(\mathrm{OH})_{2}$ coexist in the solution with $\mathrm{pH}$ value between 3 and $5, \mathrm{Hg}^{2+}$ is the dominant species at $\mathrm{pH}$ value below 3 , while at $\mathrm{pH}$ above $5, \mathrm{Hg}(\mathrm{OH})_{2}$ is the dominant species. Furthermore, according to Fatoni et al. ${ }^{38}$, at $\mathrm{pH}$ value less than $4, \mathrm{HgCl}_{2}$ is the predominant $\mathrm{Hg}^{2+}$ species. Moreover, Arias et al. ${ }^{16}$, found that $\mathrm{HgCl}_{2}$ is the predominant species for $\mathrm{pH}$ values in the range of 3.5 and 5.5, and $\mathrm{Hg}(\mathrm{OH}) \mathrm{Cl}_{\text {or }} \mathrm{HgCl}^{2-}$ are the predominant species when $\mathrm{pH}$ value is between 5.5 and 6.5 , while at $\mathrm{pH}$ value above $6.5, \mathrm{Hg}(\mathrm{OH})_{2}$ or $\mathrm{HgCl}_{4}{ }^{2-}$ are the predominant species.

As indicated in Fig. 5, that the adsorption of $\mathrm{Hg}^{2+}$ by SMRDP under different $\mathrm{pH}$ values shows almost constant adsorption behavior with maximum removal capacity $(99.7 \%)$ at $\mathrm{pH} 4$. The slight decrease in the removal percentage could be attributed to the similarity between the $\mathrm{pH}$ value and the $\mathrm{pH}_{\mathrm{PZC}}$ of the adsorbent in which both are close resulting in almost zero net charge and no significant electrostatic effect compared to $\mathrm{pH} 4^{39}$. Moreover, as mentioned earlier that at basic conditions, the adsorption decreased due to the repulsion electrostatic between the negative charged species and the adsorbent surface. The SIMRDP was another modification that was used to enhance the $\mathrm{Hg}^{2+}$ removal capacity. From Fig. 5, it was determined that the removal percentage of $\mathrm{Hg}^{2+}$ by SIMRDP increased with further increase in the solution $\mathrm{pH}$. $\mathrm{Hg}^{2+}$ removal percentage increased from $76.8 \%$ to $93.7 \%$ when $\mathrm{pH}$ increased from $\mathrm{pH} 2$ to $\mathrm{pH} 10$. This can be attributed to the fact that at low $\mathrm{pH}$ value the concentration of $\mathrm{H}^{+}$ions in the solution is high which will compete with $\mathrm{Hg}^{2+}$ on the binding sites in the adsorbent surface leading to low binding of $\mathrm{Hg}^{2+}$ ions on the active sites of the adsorbent. However, increasing the $\mathrm{pH}$ will decrease the presence of $\mathrm{H}^{+}$ions in the solution and will increase the ability of $\mathrm{Hg}^{2+}$ ions to bind to the adsorbent's surface ${ }^{32}$. According to Powell et al. ${ }^{39}$, who investigated the speciation of $\mathrm{Hg}^{2+}-\mathrm{Cl}^{-}$system the $\mathrm{pH}$ value varied between 4.0 and 8.5. It specifies that the predominating species with increasing $\mathrm{pH}$ are $\mathrm{HgCl}_{2}(\mathrm{aq})$, $\mathrm{HgOHCl}(\mathrm{aq})$, and $\mathrm{Hg}(\mathrm{OH})_{2}(\mathrm{aq})$. The other species formed in negligible amounts.

Effect of initial $\mathrm{Hg}^{2+}$ concentration on the adsorption process. Different concentrations of mercury chloride were tested in replicates to determine the efficiency of mercury adsorption onto RDP, SMRDP, and SIMRDP. The final and initial mercury concentration were determined by CVAAS analysis. From p-value $(\mathrm{P} \geq 0.05)$ shown in Table 3 , it is indicated that mercury adsorption on RDP, SMRDP, and SIMRDP was significantly affected by temperature which was confirmed more by the F-value which was found to be greater than F-critical value. However, effect of $\mathrm{pH}$ was insignificant for RDP, SMRDP, and SIMRDP as the P-value is $>0.05$ and F-value $<$ F-critical.

The effects of initial concentration on mercury adsorption onto RDP, SMRDP, and SIMRDP were examined and results showed that as the concentration increases the amount of mercury adsorbed also increases on RDP, SMRDP, and SIMRDP. This can be attributed to the vacant surface sites on the adsorbents. It was noticed that steady increases were observed between 3 and $5 \mathrm{mg} / \mathrm{g}$, and beyond $5 \mathrm{mg} / \mathrm{g}$, the adsorption capacity showed a constant adsorption behavior. This could be due to the greater number of $\mathrm{Hg}^{2+}$ in the solution than the number of the active adsorption sites in the surface of the adsorbent. Hilal et al. ${ }^{20}$, also obtained similar results, as the concentration increased the removal efficiency by $\mathrm{RDP}$ of $\mathrm{Cu}$ (II) and $\mathrm{Cd}$ (II) metal ions increased due to the overall mass transfer driving force. Samra ${ }^{40}$, discussed that adsorption capacity of RDP increases with increasing the initial concentration of the metal due to the increased diffusion of the metal in the boundary layer leading to higher sorption ability of RDP. Langmuir, Freundlich, Dubinin-Radushkevich (D-R) and Temkin models were applied to investigate the best-fit model for each adsorbent as shown in Fig. 6 . The results showed that D-R model was the best-fit model for RDP, while the Freundlich model was the best-fit model for SMRDP. However, none of the models fitted to SIMRDP.

Effect of temperature on adsorption of $\mathrm{Hg}^{2+}$. The effects of temperature on mercury adsorption onto AC, RDP, SMRDP, and SIMRDP were investigated at different temperatures, and the results are shown in Fig. 7. Figure 7a shows a linear increase of mercury adsorption onto RDP with increasing the initial concentration, which determines the availability of various active sites as the mercury concentration increases. However, from the graph (Fig. 7a), it is confirmed that when the reaction was conducted at $35^{\circ} \mathrm{C}$, the amount of mercury being adsorbed was linear until initial concentration of $5 \mathrm{mg} / \mathrm{L}$ and then it showed a constant trend indicating the inability of molecules to adhere spontaneously on the surface of the adsorbent due to the presence of few available active sites. On the other hand, at higher temperature $45^{\circ} \mathrm{C}$, different trend was observed in which it was fluctuating as shown if Fig. 7a. Overall, it can be concluded that low temperature is more favored by the process. Furthermore, the mercury adsorption onto AC (Fig. $7 \mathrm{~b}$ ) shows similar trend, as the initial concentration of mercury increased more mercury was adsorbed on AC surface; indicating the availability of active sites on the surface of the adsorbent at $25^{\circ} \mathrm{C}$. While increasing the temperature to $35^{\circ} \mathrm{C}$ and further increase to $45^{\circ} \mathrm{C}$ caused the adsorption to have a fluctuating trend of increasing and decreasing. Various studies have been conducted on the effect of temperature on the adsorption of mercury by AC and it was concluded that higher adsorption capacity was achieved with lower temperatures. Furthermore, the interaction between mercury and 

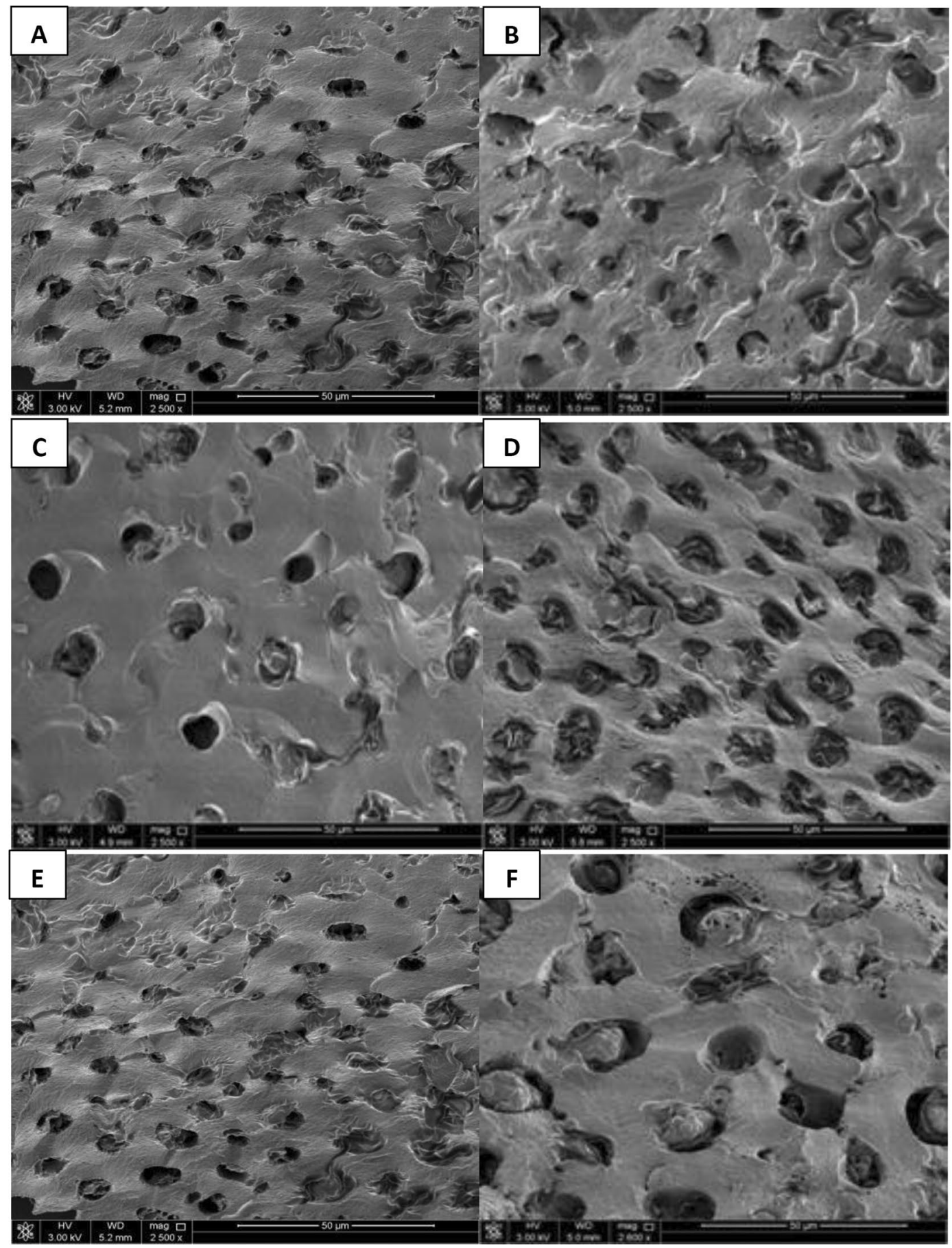

Figure 4. SEM of RDP before and after mercury adsorption of 2500x magnification and $50 \mu \mathrm{m}$ diameter. (A) Before the treatment with $\mathrm{pH} 6$ under $25^{\circ} \mathrm{C} ;(\mathbf{B}, \mathbf{C}) \mathrm{RDP}$ after the treatment with pH 6 under $25^{\circ} \mathrm{C}$; (E) before the treatment with $5 \mathrm{mg} / \mathrm{dm}^{3}$ mercury under $\mathrm{pH} 6$ and $45^{\circ} \mathrm{C} ;(\mathbf{D}, \mathbf{F})$ : after the treatment with $5 \mathrm{mg} / \mathrm{dm}^{3}$ mercury under $\mathrm{pH} 6,45^{\circ} \mathrm{C}$.

carbon takes place on disseminated active sites on the surface of the adsorbent ${ }^{41}$. Moreover, Fig. 7c, illustrates that as temperature increases the adsorbed amount of mercury by SMRDP increases up to initial mercury concentration of $3 \mathrm{mg} / \mathrm{dm}^{3}$ and then it was almost constant. On the other hand, a linear increase in the adsorption process of mercury onto SIMDRP as shown in Fig. 7d.

Adsorption thermodynamics. From Table 4, the values of $\Delta \mathrm{G}^{\circ}$ are found to have a negative value throughout the experiments except for SIMRDP, indicating that the adsorption of mercury on RDP, SMRDP, and AC is feasible and spontaneous. On the other hand, the positive value of $\Delta \mathrm{G}^{\circ}$ indicates that the adsorption process on 


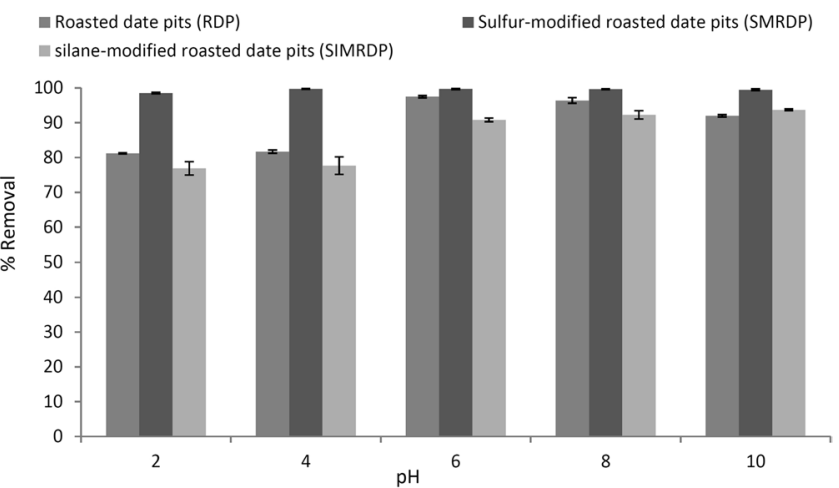

Figure 5. Effect of different $\mathrm{pH}$ values on the removal of $\mathrm{Hg}^{2+}$ from aqueous media by RDP and its modifications. Experimental conditions: initial concentration $8 \mathrm{mg} / \mathrm{dm}^{3}$; mass of adsorbent $0.05 \mathrm{~g}$; volume of the solution $50 \mathrm{ml}$; temperature $25^{\circ} \mathrm{C}$; contact time: $24 \mathrm{hr}$.
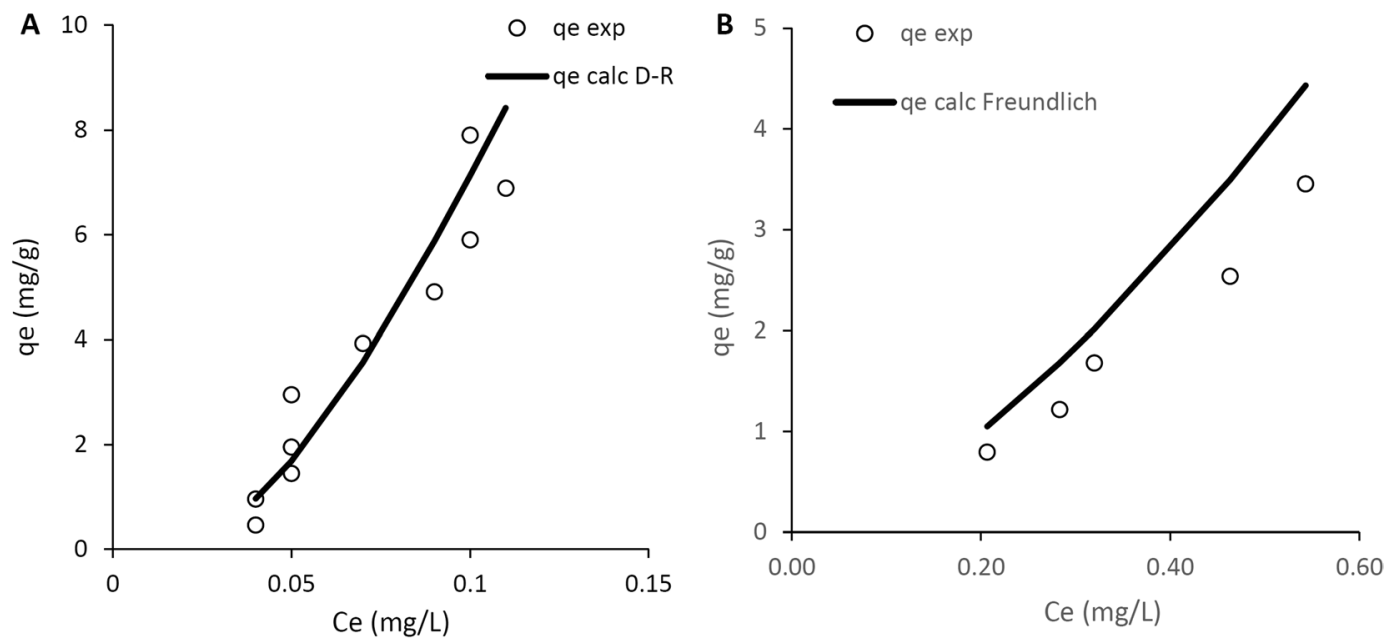

Figure 6. Best-fit adsorption isotherm models for the adsorbents tested (A) RDP and (B) SMRDP.

\begin{tabular}{|l|l|l|l|}
\hline Condition & P-value & F-value & F-critical \\
\hline Temperature RDP & 0.0087 & 2.3 & 1.8 \\
\hline Temperature SMRDP & 0.0015 & 2.8 & 1.8 \\
\hline Temperature SIMRDP & 0.0017 & 2.8 & 1.8 \\
\hline pH RDP & 0.99 & 0.0043 & 3.9 \\
\hline pH SMRDP & 0.77 & 0.27 & 3.9 \\
\hline pH SIMRDP & 0.89 & 0.12 & 3.9 \\
\hline
\end{tabular}

Table 3. Analysis of variance for the effect of $\mathrm{pH}$ and temperature on adsorption of mercury onto RDP, SMRDP, and SIMRDP.

SIMRDP was non-spontaneous. Similarly, the positive value of $\Delta \mathrm{H}^{\circ}$ indicated that the mercury adsorption onto AC, SMRDP, and SIMRDP was endothermic reaction, while the negative value of $\Delta H^{\circ}$ for RDP indicated that the reaction was exothermic. Moreover, the positive $\Delta S^{\circ}$ value onto RDP indicated the randomness for solid-liquid interface and the good affinity of mercury ions towards RDP, also it suggested that there are some changes in the structure that occurred on the surface of the adsorbent. On the other hand, the negative value of $\Delta \mathrm{S}^{\circ}$ confirmed that the adsorption of mercury on AC, SMRDP, and SIMRDP surface is an associated mechanism ${ }^{42}$.

Adsorption isotherms of mercury removal onto AC, RDP, SMRDP, and SIMRDP. The linear adsorption isotherms for mercury adsorption onto RDP, SMRDP, SIMRDP, and AC at various temperatures $\left(25^{\circ} \mathrm{C}, 35^{\circ} \mathrm{C}\right.$, and $\left.45^{\circ} \mathrm{C}\right)$ were investigated, in which the applicability of different isotherm models was verified using Langmuir and Freundlich models, also Dubinin-Radushkevich and Temkin were used for the estimation 

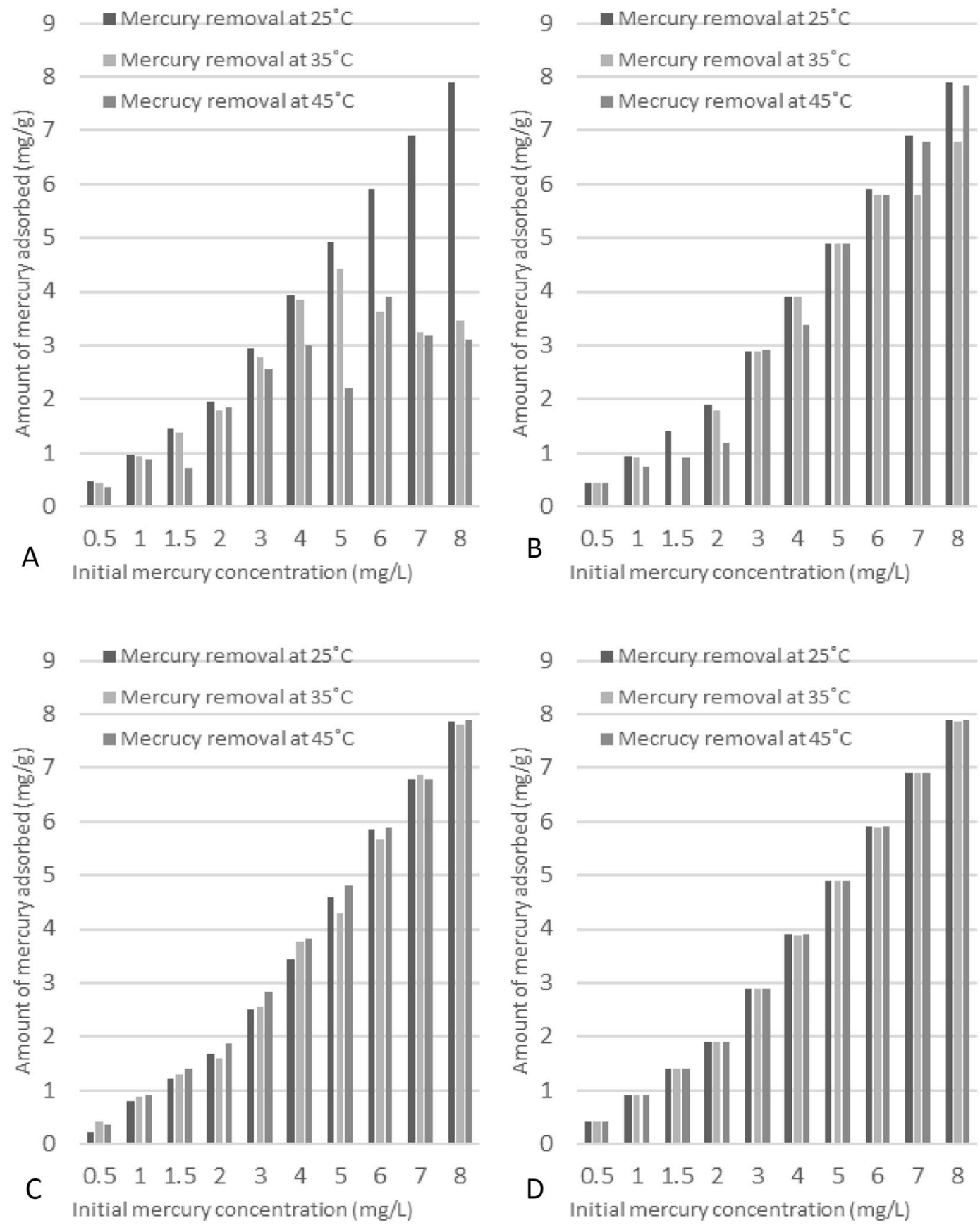

Figure 7. Effect of temperature on mercury adsorption onto (A) RDP, (B) AC, (C) SMRDP, and (D) SIMRDP. Experimental conditions: initial $\mathrm{Hg}^{2+}$ concentration 0.5 to $8 \mathrm{ppm}$; mass of adsorbent $0.05 \mathrm{~g}$; volume of the solution $50 \mathrm{ml}$; contact time: $24 \mathrm{hr}$; $\mathrm{pH} 6$ for RDP and $\mathrm{pH} 4$ for AC, SMRDP, and SIMRDP.

of certain energy parameters and their parameters and constants are shown in Table $5^{43}$. As it can be seen from Table 5, a smaller $\mathrm{R}^{2}$ value for Langmuir plot compared with Freundlich for RDP and SMRDP was obtained, which indicated that chemisorption is not the only adsorption mechanism in the process. While on the other hand, $\mathrm{R}^{2}$ value for $\mathrm{AC}$ and SIMRDP for Langmuir plot was higher than Freundlich, suggesting that for the adsorption mechanism of mercury on the different studied adsorbents, both chemisorption and physisorption should be considered under the studied concentration and temperature range $e^{44}$. Moreover, the adsorbent-adsorbate affinity was indicated by $b$ constant values, which suggested the presence of strong binding of mercury on RDP at different temperatures, as well as on SMRDP at $25^{\circ} \mathrm{C}$. However, lower $b$ values were found for other adsorbents indicating the lower binding of mercury on SMRDP, SIMRDP and AC at different temperatures. The $\mathrm{R}_{\mathrm{L}}$ values for the different adsorbents at the studied temperatures were between 0 and 1 , which indicated the favorability of the process. It is assumed by Freundlich isotherm model that mercury ion uptake occurs on heterogeneous surface without uniform distribution of adsorption heat on the surface. It can be noticed from Table 5 that $\mathrm{K}_{\mathrm{F}}$ for RDP 


\begin{tabular}{|c|c|c|c|c|c|}
\hline Adsorbent & Temperature ${ }^{\circ} \mathrm{C}$ & $\ln \left(K_{\mathrm{a}}\right)$ & $\Delta \mathrm{G}^{\circ}(\mathrm{kJ} / \mathrm{mol})$ & $\Delta \mathbf{H}^{\circ}(\mathbf{k J} / \mathrm{mol})$ & $\Delta \mathrm{S}^{\circ}(\mathrm{J} / \mathrm{mol} . \mathrm{K})$ \\
\hline \multirow{3}{*}{ RDP } & 25 & 4.077 & -10.1 & \multirow{3}{*}{-13.6} & \multirow{3}{*}{0.00980} \\
\hline & 35 & 4.63 & -11.8 & & \\
\hline & 45 & 3.74 & -9.91 & & \\
\hline \multirow{3}{*}{ AC } & 25 & 1:3.2 2: 0.93 & 1:-7.98 2:-2.20 & \multirow{3}{*}{82.6} & \multirow{3}{*}{-0.288} \\
\hline & 35 & 1:2.00 2: 4.9 & 1: $-12.42:-6.60$ & & \\
\hline & 45 & 5.1 & -12.6 & & \\
\hline \multirow{3}{*}{ SMRDP } & 25 & 1:-11.6 2: 1.90 & 1: $-28.72:-4.71$ & \multirow{3}{*}{289.3} & \multirow{3}{*}{-0.930} \\
\hline & 35 & 1: $-3.52: 3.9$ & 1: $-8.682:-9.62$ & & \\
\hline & 45 & 2.3 & -5.80 & & \\
\hline \multirow{3}{*}{ SIMRDP } & 25 & -2.30 & 5.70 & \multirow{3}{*}{56.3} & \multirow{3}{*}{-0.17} \\
\hline & 35 & -0.91 & 2.27 & & \\
\hline & 45 & -0.91 & 2.27 & & \\
\hline
\end{tabular}

Table 4. Thermodynamic parameters for mercury adsorption onto RDP, SMRDP, SIMRDP. 1 represents the high concentration values ( 4 to $\left.8 \mathrm{mg} / \mathrm{dm}^{3}\right), 2$ represents the low concentrations $\left(0.5\right.$ to $\left.3 \mathrm{mg} / \mathrm{dm}^{3}\right)$.

and SIMRDP decreased with increasing the temperature, supporting the previous findings that increasing the temperature caused a decrease in the adsorption efficiency due to the less adsorption capacity. Furthermore, the value of $n$ was $<1$ and $1 / n$ was $>1$ for all the adsorbents except SMRDP, which reveals that mercury adsorption process is favorable and heterogenous under these conditions.

Two lines were obtained at low and high concentrations when the data of $\mathrm{Hg}^{2+}$ adsorption on $\mathrm{AC}$ and SMRDP were plotted according to the linearized form of Langmuir isotherm model. According to Khraisheh et al. ${ }^{32}$, and $\mathrm{Al}$-degs et $a \mathrm{l} .^{45}$, the presence of these two lines indicates that two different types of adsorption sites exist having a wide binding energies spectrum on the adsorbent's surface. $\mathrm{Hg}^{2+}$ will be attracted to the active sites with the highest energy and there will be a decrease in the tendency of ion adsorption each time another adsorbs ${ }^{24}$. Moreover, Table 6 below shows the maximum adsorption capacity of mercury by different carbon-containing adsorbents.

In order to find the most-stable $\mathrm{Hg}^{2+}$ covered on the adsorbents surface, $\mathrm{E}_{\mathrm{D}}$ from the Dubinin-Radushkevich adsorption model was used. This approach was used to distinguish between the physical and chemical adsorption of $\mathrm{Hg}^{2+}$ ions. This could be examined by calculating the mean free energy, $\mathrm{E}_{\mathrm{D}}$ per molecule of adsorbate (for removing an ion from its location in the adsorption space to the infinity). In addition, the stability of the adsorbed $\mathrm{Hg}^{2+}$ on the adsorbents system can be estimated by its $\mathrm{E}_{\mathrm{D}}$.

For example, in the $\mathrm{Hg}^{2+}$ adsorbed RDP system, the $\mathrm{E}_{\mathrm{D}}$ was calculated according to the (4),

$$
\Delta E_{D}=\left[E\left(\mathrm{Hg}^{2+} \text { adsorbed on } R D P-\left(E(R D P)+E\left(H g^{2+}\right)\right)\right]\right.
$$

where $\mathrm{E}\left(\mathrm{Hg}^{2+}\right.$ adsorbed on $\left.\mathrm{RDP}\right), \mathrm{E}(\mathrm{RDP})$ and $\mathrm{E}\left(\mathrm{Hg}^{2+}\right)$ is total energies of the $\mathrm{Hg}^{2+}$ adsorbed $\mathrm{RDP}$ system, the RDP surface and a single $\mathrm{Hg}^{2+}$ atom, respectively.

Based on the above analysis of $\mathrm{Hg}^{2+}$ adsorption, it can be suggested that the $\mathrm{Hg}^{2+}$ ions are easy to form on the surface of the SIMRDP with the lowest adsorption energy $\left(707.1 \mathrm{~kJ} \mathrm{~mol}^{-1}\right)$, while the SMRDP and the RDP were the highest. This would be due to the stable configuration between the $\mathrm{Hg}^{2+}$ and the SIMRDP. The variation on the adsorption profile of $\mathrm{Hg}^{2+}$ ions into the surface of the adsorbents would be due to the $\mathrm{Hg}^{2+}$ oxidation and reduction. Once the $\mathrm{Hg}^{2+}$ adsorbed on the surface of the adsorbent may undergo an equilibrium of reduction and oxidation; $\mathrm{Hg}^{2+} \leftrightarrows \mathrm{Hg}^{+} \leftrightarrows \mathrm{Hg}$ ). Consequently, the configuration would be changed according to the state of the $\mathrm{Hg}$ and the amount of energy required for adsorption. Two main paths for $\mathrm{Hg}^{2+}$ redox equilibrium on the adsor-

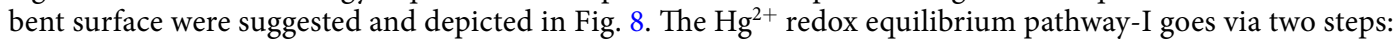
$\mathrm{Hg}^{2+}$ (ads), $\mathrm{Hg}^{+}$(ads), and $\mathrm{Hg}(\mathrm{ads})$. The pathway-II directly goes via one step: $\mathrm{Hg}^{2+}$ (ads) and $\mathrm{Hg}$ (ads).

Furthermore, it is shown from $\mathrm{R}_{\mathrm{L}}, \mathrm{n}$ and $1 / \mathrm{n}$ values that the adsorption process is not irreversible, and it is favorable. Lata ${ }^{46}$, discussed the desorption characteristics of mercury using novel animated chitosan bead by using several different desorbing agents such as $\mathrm{EDTA}, \mathrm{HCl}$, and $\mathrm{HNO}_{3}$. It is recommended from the desorption results that EDTA is the best agent for the desorbing process of $95 \%$ while $65 \%$ and $61 \%$ were achieved by using $\mathrm{HCl}$ and $\mathrm{HNO}_{3}$, respectively. Moreover, the adsorbent reusability was determined by the repetition of the adsorption-desorption cycles up to 5 times, and results showed that the recycled beads has maintain the adsorption capacity at $90 \%$ level up to the $5^{\text {th }}$ cycle. In addition, good mercury desorption from activated carbon fiber and silver-loaded activated carbon fiber was reported by Kuang ${ }^{47}$, in which results showed that mercury desorption from activated carbon fiber was $69.93 \%$, however, when activated carbon was loaded with silver, its adsorption and desorption properties were improved to $97.73 \%$. Moreover, El-Naas ${ }^{48}$ investigated the regeneration process of spent date pits by chemical regeneration and thermal regeneration. Results showed that thermal regeneration lead to low regeneration efficiencies in the fourth cycle compared to the first cycle, which can be attributed to the expansion of pore of date pits pores because of the treatment. On the other hand, the chemical regeneration gave promising results in which $86 \%$ regeneration efficiency was achieved by using ethanol after the $4^{\text {th }}$ cycle and $66 \%$ was reached by using a combination of hydrogen peroxide, ethanol and $\mathrm{NaOH}$ after the $4^{\text {th }}$ cycle, while using $\mathrm{HCl}$ and $\mathrm{NaOH}$ did not give good regeneration efficiencies of date pits. Thus, the literature shows that the regeneration of date pits will be determined by the technique used as well as the adsorbate. Therefore, further research will be conducted to investigate the regeneration and desorption efficiency for date pits used for mercury removal from water. 


\begin{tabular}{|c|c|c|c|c|c|c|c|c|}
\hline & \multirow[b]{2}{*}{$\mathbf{T}\left({ }^{\circ} \mathrm{C}\right)$} & \multicolumn{3}{|l|}{ Langmuir } & \multicolumn{4}{|l|}{ Freundlich } \\
\hline & & $q_{0}(\mathrm{mg} / \mathrm{g})$ & b $\left(\mathrm{dm}^{3} / \mathrm{mg}\right)$ & $\mathbf{R}^{2}$ & $\mathrm{~K}_{\mathrm{F}}(\mathrm{mg} / \mathrm{g})(\mathrm{L} / \mathrm{g})^{\mathrm{n}}$ & $\mathbf{n}$ & $1 / n$ & $\mathbf{R}^{2}$ \\
\hline \multirow{8}{*}{$\mathrm{RDP}$} & 25 & 28.0 & 59.0 & 0.82 & 69.0 & 0.460 & 2.15 & 0.853 \\
\hline & 35 & 560 & 102 & 0.843 & 10 & 2.90 & 0.345 & 0.967 \\
\hline & 45 & 370 & 42.4 & 0.768 & $\begin{array}{l}1: 19.7 \\
2: 1.4\end{array}$ & \begin{tabular}{|l|l|}
$1: 0.899$ \\
2: 0.968
\end{tabular} & $\begin{array}{l}1: 1.11 \\
2: 1.03\end{array}$ & $\begin{array}{l}\text { 1: } 0.620 \\
\text { 2: } 0.871\end{array}$ \\
\hline & & \multicolumn{3}{|l|}{ Temkin } & \multicolumn{4}{|c|}{ Dubinin-Radushkevich } \\
\hline & $\mathrm{T}\left({ }^{\circ} \mathrm{C}\right)$ & $A_{\mathrm{T}}\left(\mathbf{d m}^{3} / \mathbf{m g}\right)$ & B (J/mol) & $\mathbf{R}^{2}$ & $Q_{s}(\mathrm{mg} / \mathrm{g})$ & $\mathbf{K}$ & \multicolumn{2}{|l|}{$\mathbf{R}^{2}$} \\
\hline & 25 & 27.8 & 6.26 & 0.925 & 75.6 & $8.0 \times 10^{-8}$ & \multicolumn{2}{|l|}{0.871} \\
\hline & 35 & 42.4 & 0.985 & 0.745 & 4.54 & $-5.0 \times 10^{-8}$ & \multicolumn{2}{|l|}{0.914} \\
\hline & 45 & 38.3 & 0.639 & 0.559 & 2.79 & $-6.0 \times 10^{-8}$ & \multicolumn{2}{|l|}{0.537} \\
\hline \multirow{10}{*}{ SMRDP } & & \multicolumn{3}{|l|}{ Langmuir } & \multicolumn{4}{|l|}{ Freundlich } \\
\hline & $\mathrm{T}\left({ }^{\circ} \mathrm{C}\right)$ & $Q_{\circ}(\mathrm{mg} / \mathrm{g})$ & b $\left(\mathbf{d m}^{3} / \mathbf{m g}\right)$ & $\mathbf{R}^{2}$ & $\mathbf{K}_{\mathrm{F}}(\mathrm{mg} / \mathrm{g})(\mathrm{L} / \mathrm{g})^{\mathrm{n}}$ & $\mathbf{n}$ & $1 / n$ & $\mathbf{R}^{2}$ \\
\hline & 25 & $\begin{array}{l}1: 280 \\
2: 330\end{array}$ & $\begin{array}{l}1: 8.31 \\
2: 139.2\end{array}$ & \begin{tabular}{|l|}
$1: 0.979$ \\
$2: 0.875$
\end{tabular} & $\begin{array}{l}\text { 1: } 11.0 \\
2: 21.0\end{array}$ & $\begin{array}{l}1: 0.67 \\
2: 2.42\end{array}$ & $\begin{array}{l}\text { 1: } 1.49 \\
\text { 2: } 0.41\end{array}$ & $\begin{array}{l}\text { 1: } 0.989 \\
\text { 2: } 0.793\end{array}$ \\
\hline & 35 & $\begin{array}{l}1: 280 \\
2: 330\end{array}$ & \begin{tabular}{|l|}
$1: 8.3$ \\
$2: 139.2$
\end{tabular} & \begin{tabular}{|l|}
$1: 0.98$ \\
$2: 0.88$
\end{tabular} & $\begin{array}{l}\text { 1: } 16.2 \\
2: 11.3\end{array}$ & $\begin{array}{l}1: 1.09 \\
2:-3.51\end{array}$ & $\begin{array}{l}1: 0.920 \\
2:-0.285\end{array}$ & $\begin{array}{l}\text { 1: } 0.871 \\
\text { 2: } 0.534\end{array}$ \\
\hline & 45 & 503 & 48.5 & 0.918 & 52 & 0.448 & 2.2305 & 0.9934 \\
\hline & & \multicolumn{3}{|l|}{ Temkin } & \multicolumn{4}{|c|}{ Dubinin-Radushkevich } \\
\hline & $\mathrm{T}\left({ }^{\circ} \mathrm{C}\right)$ & $\mathbf{A}_{\mathrm{T}}\left(\mathbf{d m}^{3} / \mathbf{m g}\right)$ & B (J/mol) & $\mathbf{R}^{2}$ & $Q_{s}(\mathrm{mg} / \mathrm{g})$ & $\mathbf{K}$ & \multicolumn{2}{|l|}{$\mathbf{R}^{2}$} \\
\hline & 25 & $\begin{array}{l}1: 0.22 \\
2:-0.03\end{array}$ & $\begin{array}{l}1: 3.02 \\
2: 2.41\end{array}$ & $\begin{array}{l}1: 0.861 \\
2: 0.734\end{array}$ & $\begin{array}{l}: 6.92 \\
2: 3.55\end{array}$ & $\begin{array}{l}1: 1.0 \times 10^{-7} \\
2: 3.0 \times 10^{-8}\end{array}$ & \multicolumn{2}{|l|}{$\begin{array}{l}: 0.980 \\
2: 0.813\end{array}$} \\
\hline & 35 & $\begin{array}{l}\text { 1: } 17.6 \\
2: 0.140\end{array}$ & $\begin{array}{l}1: 1.084 \\
2:-1.67\end{array}$ & $\begin{array}{l}1: 0.863 \\
2: 0.592\end{array}$ & $\begin{array}{l}: 3.36 \\
2: 3.76\end{array}$ & $\begin{array}{l}1:-6.0 \times 10^{-8} \\
2: 2.0 \times 10^{-8}\end{array}$ & \multicolumn{2}{|l|}{$\begin{array}{l}: 0.882 \\
2: 0.623\end{array}$} \\
\hline & 45 & 11.9 & 5.19 & 0.958 & 32.8 & $-1.0 \times 10^{-7}$ & \multicolumn{2}{|l|}{0.993} \\
\hline \multirow{10}{*}{ SIMRDP } & & \multicolumn{3}{|l|}{ Langmuir } & \multicolumn{4}{|l|}{ Freundlich } \\
\hline & $\mathrm{T}\left({ }^{\circ} \mathrm{C}\right)$ & $Q_{\circ}(\mathrm{mg} / \mathrm{g})$ & $\mathbf{b}\left(\mathrm{dm}^{3} / \mathrm{mg}\right)$ & $\mathbf{R}^{2}$ & $\mathbf{K}_{\mathbf{F}}(\mathrm{mg} / \mathrm{g})(\mathrm{L} / \mathrm{g})^{\mathrm{n}}$ & $\mathbf{n}$ & $1 / n$ & $\mathbf{R}^{2}$ \\
\hline & 25 & 90.0 & 0.10 & 0.790 & 70.0 & 0.0300 & 33.0 & 0.731 \\
\hline & 35 & -20 & -0.399 & 0.7875 & 18.2 & 0.132 & 7.58 & 0.851 \\
\hline & 45 & -20 & -0.4 & 0.759 & 18.1 & 0.120 & 8.33 & 0.850 \\
\hline & & \multicolumn{3}{|l|}{ Temkin } & \multicolumn{4}{|c|}{ Dubinin-Radushkevich } \\
\hline & $\mathrm{T}\left({ }^{\circ} \mathrm{C}\right)$ & $A_{\mathrm{T}}\left(\mathbf{d m}^{3} / \mathbf{m g}\right)$ & B (J/mol) & $\mathbf{R}^{2}$ & $Q_{s}(\mathrm{mg} / \mathrm{g})$ & $\mathbf{K}$ & \multicolumn{2}{|l|}{$\mathbf{R}^{2}$} \\
\hline & 25 & 0.38 & 95.6 & 0.699 & $1.5 \times 10^{-17}$ & $1.0 \times 10^{-6}$ & 0.729 & \\
\hline & 35 & 11.6 & 19.6 & 0.775 & $5.26 \times 10^{4}$ & $-3.0 \times 10^{-7}$ & 0.861 & \\
\hline & 45 & 0.999 & $5.0 \times 10^{-8}$ & 0.569 & 0.876 & -0.0783 & 0.544 & \\
\hline & & Langmuir & & & Freundlich & & & \\
\hline & $\mathrm{T}\left({ }^{\circ} \mathrm{C}\right)$ & $Q_{\circ}(\mathbf{m g} / \mathrm{g})$ & $\mathbf{b}\left(\mathrm{dm}^{3} / \mathrm{mg}\right)$ & $\mathbf{R}^{2}$ & $\mathbf{K}_{\mathbf{F}}(\mathrm{mg} / \mathrm{g})(\mathrm{L} / \mathrm{g})^{\mathrm{n}}$ & $\mathbf{n}$ & $1 / n$ & $\mathbf{R}^{2}$ \\
\hline & 25 & $\begin{array}{l}1: 58.0 \\
2: 120\end{array}$ & $\begin{array}{l}1: 2.53 \\
2: 25.1\end{array}$ & $\begin{array}{l}: 0.598 \\
2: 0.856\end{array}$ & 79.0 & 0.280 & 3.60 & 0.516 \\
\hline & 35 & 930 & 147.6 & 0.98 & $\begin{array}{l}1:-0.22 \\
2: 18.0\end{array}$ & $\begin{array}{l}1:-1.16 \\
2: 5.84\end{array}$ & $\begin{array}{l}1:-0.861 \\
2: 0.171\end{array}$ & $\begin{array}{l}1: 0.571 \\
2: 0.588\end{array}$ \\
\hline$A C$ & 45 & -648 & -163 & 0.751 & 50.1 & 0.649 & 1.53 & 0.794 \\
\hline $\mathrm{AC}$ & & Temkin & & & Dubinin-Radush & & & \\
\hline & $\mathrm{T}\left({ }^{\circ} \mathrm{C}\right)$ & $A_{T}\left(\mathrm{dm}^{3} / \mathrm{mg}\right)$ & B (J/mol) & $\mathbf{R}^{2}$ & $\mathrm{Q}_{\mathrm{s}}(\mathrm{mg} / \mathrm{g})$ & $\mathbf{K}$ & $\mathbf{R}^{2}$ & \\
\hline & 25 & $\begin{array}{l}\text { 1: } 0.26 \\
\text { 2: } 0.66\end{array}$ & $\begin{array}{l}1: 2.69 \\
2: 6.76\end{array}$ & $\begin{array}{l}: 0.888 \\
2: 0.517\end{array}$ & $\begin{array}{l}1: 33.7 \\
2: 2.3 \times 10^{-4}\end{array}$ & $\begin{array}{l}1: 9.0 \times 10^{-8} \\
2: 3.0 \times 10^{-7}\end{array}$ & $\begin{array}{l}: 0.366 \\
2: 0.856\end{array}$ & \\
\hline & 35 & 0.631 & -1.42 & 0.605 & $\begin{array}{l}1: 0.131 \\
2: 6.56\end{array}$ & $\begin{array}{l}1: 6.0 \times 10^{-8} \\
2: 1.0 \times 10^{-8}\end{array}$ & \begin{tabular}{|l|}
$1: 0.373$ \\
$2: 0.6926$
\end{tabular} & \\
\hline & 45 & 17.6 & 8.03 & 0.896 & 41.8 & $-8.0 \times 10^{-8}$ & 0.826 & \\
\hline
\end{tabular}

Table 5. The parameters of various isotherms models for mercury adsorption on RDP, SMRDP, SIMRDP, and $\mathrm{AC}$ at $25^{\circ} \mathrm{C}, 35^{\circ} \mathrm{C}$, and $45^{\circ} \mathrm{C}$. 1 represents the low concentrations $\left(0.5\right.$ to $\left.3 \mathrm{mg} / \mathrm{dm}^{3}\right), 2$ represents the high concentration values $\left(4\right.$ to $\left.8 \mathrm{mg} / \mathrm{dm}^{3}\right)$.

\section{Conclusion}

Using date pits to remove contaminant from the environment is very beneficial as it is considered as an agricultural waste; by using it, we will apply the concept of sustainable development. Obtained results illustrates that higher $\mathrm{Hg}^{2+}$ concentration cause an increase in the adsorption process of all adsorbents until reaching a concentration in the range of 4 to $5 \mathrm{mg} / \mathrm{dm}^{3}$. Studying the isotherm models showed that there is higher correlation of the results with Langmuir isotherm model than Freundlich isotherm model, with higher $\mathrm{R}^{2}$ value for RDP and SMRDP. While on the other hand, Freundlich isotherm model was the best-fit model for AC and SIMRDP with higher $\mathrm{R}^{2}$. In addition, RDP, SMRDP, and AC has spontaneous adsorption process, while SIMRDP has non-spontaneous adsorption process. Similarly, AC, SMRDP, and SIMRDP adsorption process was endothermic, 


\begin{tabular}{|l|l|l|l|l|}
\hline Adsorption isotherm model & \multirow{3}{*}{} & Langmuir & Freundlich & \\
\cline { 5 - 6 } Adsorbent & $\mathbf{p H}$ & $\mathbf{q}_{\circ}(\mathbf{m g} / \mathbf{g})$ & $\mathbf{K}_{\mathbf{F}}(\mathbf{m g} / \mathbf{g})(\mathbf{L} / \mathbf{g})$ & Reference \\
\hline RDP & 6 & 282 & 69 & This work \\
\hline AC & 4 & 120 & 79 & This work \\
\hline SMRDP & 4 & 280 & 11 & This work \\
\hline SIMRDP & 4 & 90 & 70 & This work \\
\hline Coal fly ash & 2.5 & 0.44 & 0.26 & 44 \\
\hline Peel biomass of Pachira aquatica Aubl & - & 0.71 & 0.58 & 49 \\
\hline Activated carbon from Rosmarinus officinalis Leaves & 7.58 & - & 1.25 & 50 \\
\hline Activated carbon from mango kernel & 6.5 & 19.762 & 7.521 & 51 \\
\hline Palm shell powder & $6-7$ & 7.134 & 0.126 & 52 \\
\hline Spanish broom plant & 5 & 20 & $0.6(\mathrm{mg} / \mathrm{g})(\mathrm{L} / \mathrm{g})$ & 16 \\
\hline
\end{tabular}

Table 6. Maximum adsorption capacity of mercury ions into different adsorbents at $25^{\circ} \mathrm{C}$.

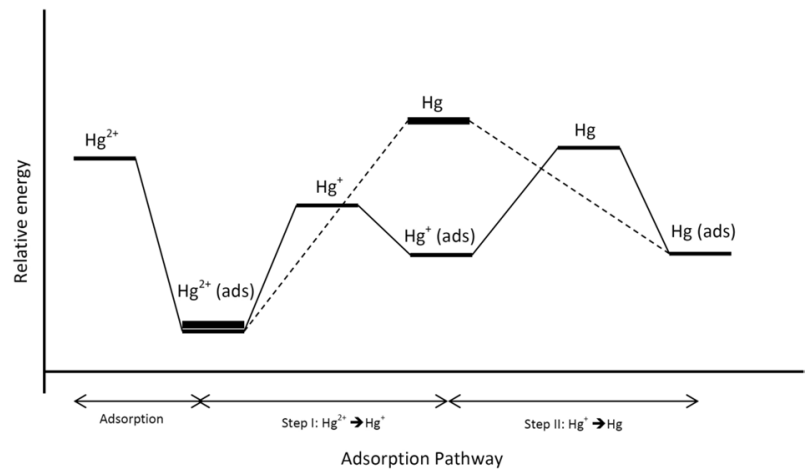

Figure 8. Adsorption pathways and relative energy profile of $\mathrm{Hg}^{2+}$ adsorption on the surface of adsorbent ${ }^{53}$.

while RDP was exothermic. Furthermore, FTIR analysis showed that carboxylic group is the main functional group found in the surface of RDP and its modification, while main functional group on the surface of AC is hydroxyl group. Moreover, SMRDP has the highest $\mathrm{Hg}^{2+}$ adsorption compared to other known adsorbents. It was found that the adsorbents from the carbon sulfide process displayed the best performance. The results demonstrate that RDP with proper modification can be a very promising low-cost adsorbent for the removal of $\mathrm{Hg}^{2+}$ from aqueous media.

Received: 23 November 2018; Accepted: 3 October 2019;

Published online: 25 October 2019

\section{References}

1. Abbas, K., Znad, H. \& Awual, R. A ligand anchored conjugate adsorbent for effective mercury(II) detection and removal form aqueous media. Chem. Eng. J. 334, 432-443 (2018).

2. Binnemans, K. \& Jones, P. T. Perspective for the recovery of rare earths from end-of-life fluorescent lamps. J. Rare Earths. 32(3), 195 (2014).

3. Kabiri, S., Diana, N. H. T., Azari, S. \& Losic, D. Graphene-Diatom silica aerogels for efficient removal of mercury from water. ACSAppl. Mater. Interfaces. 7(22), 11815-11823 (2015).

4. Sorbal, L., Yallouz A.V. \& Fernandes, A.L. Treatment of mercury bearing fluorescent lamps by using electrochemical process. CETEM - Centre for Mineral Technology. (2006).

5. Ozgur, C. et al. Combined oxidative leaching and electrowinning process for mercury recovery from spent fluorescent lamps. Waste Manage. 57, 215-219 (2016).

6. Bussi, J. et al. The recovery and recycling of mercury from fluorescent lamps using photocatalytic techniques. J. Chem. Tech. Biotech. 85 (2010).

7. Al-Ghouti, M., Abuqaoud, R. \& Abu-Dieyeh, M. Detoxification of mercury pollutant leached from spent fluorescent lamps using bacterial strains. Waste Manage. 49, 238-244 (2016).

8. Ahmad, T. et al. The use of date palm as a potential adsorbent for wastewater treatment: a review. Environ. Sci. Pollut. Res. 19, 1464-1484 (2011).

9. O'Connell, D., Birkinshaw, C. \& O’Dwyer, T. Heavy metal adsorbents prepared from the modification of cellulose: A review. Bioresour. Technol. 99, 6709-6724 (2008).

10. Innocenzi, V. et al. Application of solvent extraction operation to recover rare earths from fluorescent lamps. J. Clean. Prod. 172, 2840-2852 (2018).

11. Poste, A. E., Pastukhov, M. V., Braaten, H. F. V., Qzersky, T. \& Moore, M. Past and present mercury accumulation in the Lake Baikal seal: Temporal trends, effects of life history, and toxicological implications. Environ. Toxicol. Chem. 37(5), 1476-1486 (2018).

12. Li, R., et al Mercury pollution in vegetables, grains and soils from areas surrounding coal-fired power plants. Scientific Reports. 7 (2017). 
13. Awual, R. M. D. Novel nanocomposite materials for efficient and selective mercury ions capturing from wastewater. Chem. Eng. J. 307, 456-465 (2017).

14. Lecler, M. et al. Improving the work environment in the fluorescent lamp recycling sector by optimizing mercury elimination. Waste Management 76, 250-260 (2018).

15. Igwe, J. \& Abia, A. Adsorption isotherm studies of $\mathrm{Cd}$ (II), $\mathrm{Pb}$ (II) and $\mathrm{Zn}$ (II) ions bioremediation from aqueous solution using unmodified and EDTA-modified maize cob. Eclét. Quím. 32, 33-42 (2007).

16. Arias Arias, F., Beneduci, A., Chidichimo, F., Furia, E. \& Straface, S. Study of the adsorption of mercury (II) on lignocellulosic materials under static and dynamic conditions. Chemosphere. 180, 11-23 (2017).

17. Al-Ghouti, M., Al Disi, Z., Al-Kaabi, N. \& Khraisheh, M. Mechanistic insights into the remediation of bromide ions from desalinated water using roasted date pits. Chem. Eng. J. 308, 463-475 (2017).

18. Ahmed, M. Preparation of activated carbons from date (Phoenix dactylifera L.) palm stones and application for wastewater treatments: Review. Process. Saf. Environ. 102, 168-182 (2016).

19. Mohammadi, M., Soltani, M., Siahpoosh, A. \& Shamsaei Mehrjan, M. Effects of Date Palm (Phoenix dactylifera) Seed Extract on Heavy Metals Concentrations in Carp (Cyprinus carpio). Pol. J. Environ. Stud. 25, 1117-1123 (2016).

20. Hilal, N., Ahmed, I. \& El-Sayed, R. Activated and Nonactivated Date Pits Adsorbents for the Removal of Copper(II) and Cadmium(II) from Aqueous Solutions. Int. Sch. Res. Notices Phys. Chem. 2012, 1-11 (2012).

21. Tran, H., You, S. \& Chao, H. Thermodynamic parameters of cadmium adsorption onto orange peel calculated from various methods: A comparison study. J. Environ. Chem. Eng. 4, 2671-2682 (2016).

22. Chaudhry, S., Zaidi, Z. \& Siddiqui, S. Isotherm, kinetic and thermodynamics of arsenic adsorption onto Iron-Zirconium Binary Oxide-Coated Sand (IZBOCS): Modelling and process optimization. J. Mol. Liq. 229, 230-240 (2017).

23. Al-Anber, M. Thermodynamics Approach in the Adsorption of Heavy Metals in Thermodynamics - Interaction Studies - Solids, Liquids and Gases. 745-746 (2011).

24. Foo, K. \& Hameed, B. Insights into the modeling of adsorption isotherm systems. Chem. Eng. J. 156, 2-10 (2010).

25. Shahbeig, H., Bagheri, N., Ghorbanian, S., Hallajisani, A. \& Poorkarimi, S. A new adsorption isotherm model of aqueous solutions on granular activated carbon. World J. Modelling Simulation. 9, 243-254 (2013).

26. Shweta, K. \& Jha, H. Rice husk extracted lignin-TEOS biocomposites: Effects of acetylation and silane surface treatments for application in nickel removal. Biotechnol. Reports. 7, 95-106 (2015).

27. Chen, X. Modeling of Experimental Adsorption Isotherm Data. Information. 6, 14-22 (2015).

28. Duman, O., Tunç, S. \& Gürkan Polat, T. Adsorptive removal of triarylmethane dye (Basic Red 9) from aqueous solution by sepiolite as effective and low-cost adsorbent. Microporous Mesoporous Mater. 210, 176-184 (2015).

29. Mohammed, T., Azeez, R. \& Lutffe, T. Biosorption of Copper from Synthesized Wastewater Using Agriculture Waste (Roasted Date Pits). Int. J. Recent Sci. Res. 6, 3063-3068 (2015).

30. Schwartz, M. Interpretation of Infrared Spectra (1st ed.). Boston, Massachusetts: UMass Boston OpenCourseWare (2018).

31. Piccin, J., Dotto, G. \& Pinto, L. Adsorption isotherms and thermochemical data of FD\&C Red n ${ }^{\circ} 40$ binding by Chitosan. Braz. J. Chem. Eng. 28, 295-304 (2011).

32. Khraisheh, M., Al-Ghouti, M., Allen, S. \& Ahmad, M. The Effect of pH, Temperature, and Molecular Size on the Removal of Dyes from Textile Effluent Using Manganese Oxides-Modified Diatomite. Water Environ. Fed. 76, 2655-2663 (2004).

33. Song, B., Eom, Y. \& Lee, T. Removal and recovery of mercury from aqueous solution using magnetic silica nanocomposites. Appl. Surface Sci. 257, 4754-4759 (2011).

34. Ihsanullah, A. et al. Heavy metal removal from aqueous solution by advanced carbon nanotubes: Critical review of adsorption applications. Sep. Purif. Technol. 157, 141-161 (2016).

35. Bobirică, C., Dumitrescu, S., Olescu, A. \& Stănescu, R. Leaching Behavior of Mercury from Spent Fluorescent Lamps Solidified with Cement. 2, 266-270 (2014).

36. Silva, H., Ruiz, S., Granados, D. \& Santángelo, J. Adsorption of mercury (II) from liquid solutions using modified activated carbons. Mat. Res. 13, 129-134 (2010).

37. Zhang, F., Nriagu, J. \& Itoh, H. Mercury removal from water using activated carbons derived from organic sewage sludge. Water Res. 39, 389-395 (2005).

38. Fatoni, A., Koesnarpadi, S. \& Hidayati, N. Synthesis, Characterization of Cellulose Modified with 2-Mercaptobenzothiazole and Its Adsorption To Cu(II) Ion in Aqueous Solution. Indonesian J. Chem. 15, 194 (2015).

39. Powell, K. J. et al. Chemical Speciation of Environmentally Significant Heavy Metals with Inorganic Ligands. Pure Appl. Chem. 77, 739-800 (2005).

40. Samra, S. Biosorption of $\mathrm{Pb} 2+$ from Natural Water using Date Pits: A Green Chemistry Approach. Mod. Chem. Appl. 2 (2014).

41. Karatza, D., Lancia, A., Musmarra, D. \& Zucchini, C. Study of mercury absorption and desorption on sulfur impregnated carbon. Exp. Therm. Fluid Sci. 21, 150-155 (2000).

42. Imran Din, M., Mirza, M., Ata, S., Athar, M. \& Mohsin, I. Thermodynamics of Biosorption for Removal of Co(II) Ions by an Efficient and Ecofriendly Biosorbent (Saccharum bengalense): Kinetics and Isotherm Modeling. J. Chem. 2013, 1-11 (2013).

43. Itodo, A. \& Itodo, H. Sorption Energies Estimation Using Dubinin-Radushkevich and Temkin Adsorption Isotherms. Life Sci. J. 7, $31-39(2010)$

44. Attari, M., Bukhari, S., Kazemian, H. \& Rohani, S. A low-cost adsorbent from coal fly ash for mercury removal from industrial wastewater. J. Environ. Chem. Eng. 5, 391-399 (2017).

45. Aldegs, Y., Elbarghouti, M., Elsheikh, A. \& Walker, G. Effect of solution pH, ionic strength, and temperature on adsorption behavior of reactive dyes on activated carbon. Dye. Pig. 77, 16-23 (2008).

46. Lata, S., Singh, P. K. \& Samadder, R. Regeneration of adsorbents and recovery of heavy metals: a review. Int. J. Environ. Technol. 12, $1461-1478$ (2015).

47. Kuang, M., Yang, G., Chen, W. \& Zhang, Z. Study on mercury desorption from silver-loaded activated carbon fibre and activated carbon fibre. J. Fuel Chem. Technol. 36(4), 468-473 (2008).

48. El-Naas, M. H., Al-Zuhair, S. \& Abu Alhaija, M. Removal of phenol from petroleum refinery wastewater through adsorption on date-pit activated carbon. Chem. Eng. J. 162, 997-1005 (2010).

49. Santana, A., dos Santos, W., Silva, L. \& das Virgens, C. Removal of mercury(II) ions in aqueous solution using the peel biomass of Pachira aquatica Aubl: kinetics and adsorption equilibrium studies. Environ. Monitor. Assess. 188 (2016).

50. Erhayem, M., Al-Tohami, F., Mohamed, R. \& Ahmida, K. Isotherm, Kinetic and Thermodynamic Studies for the Sorption of Mercury (II) onto Activated Carbon from Rosmarinus officinalis; Leaves. Am. J. Analyt. Chem. 6, 1-10 (2015).

51. Somayajula, A., Aziz, A., Saravanan, P. \& Matheswaran, M. Adsorption of mercury (II) ion from aqueous solution using low-cost activated carbon prepared from mango kernel. Asia-Pac. J. Chem. Eng. 8, 1-10 (2012).

52. Kushwaha, S., Sodaye, S. \& Padmaja, P. Equilibrium, Kinetics and Thermodynamic Studies for Adsorption of Hg (II) on Palm Shell Powder. World Acad. Sci. Eng. Technol. 19, 597-603 (2008).

53. Xu, Z. et al. First principles study of adsorption and oxidation mechanism of elemental mercury by $\mathrm{HCl}$ over MoS2 $\left(\begin{array}{ll}1 & 0\end{array}\right)$ surface. Chemical Engineering Journal, 308, 1225-1232(2017). 


\section{Acknowledgements}

This paper was made possible by UREP grant \# (17-066-1-004) from the Qatar national research fund (a member of Qatar foundation). The statements made herein are solely the responsibility of the author(s). The authors would like to thank the Environmental Science Center - Qatar University in analyzing mercury ions in the samples, and the Central Laboratory Unit at Qatar University for performing the FTIR and SEM for the samples. The authors would also thank Dr Basem Shomar, Ms. Fatma Fahraei, Ms. Mariem Safi, Ms. Sana Khan, Ms. Maymoona Ayesh, and Ms. Haya Alduroobi for their participation in this UREP project. Special thanks to Mr. M. Y. Ashfaq for his efforts in reading the final version of the manuscript. The publication of this article was funded by the Qatar National Library.

\section{Author contributions}

Mohammad A. Al-Ghouti and Dana Da'ana designed the experiments. Dana Da'ana performed the experiments. Dana Da'ana and Mohammad A. Al-Ghouti performed data analysis. Dana Da'ana and Mohammad A. Al-Ghouti wrote the manuscript. Mohammed Abu-Dieyeh and Majeda Khraisheh contributed to data analysis, editing and reviewing the manuscript.

\section{Competing interests}

The authors declare no competing interests.

\section{Additional information}

Correspondence and requests for materials should be addressed to M.A.A.-G.

Reprints and permissions information is available at www.nature.com/reprints.

Publisher's note Springer Nature remains neutral with regard to jurisdictional claims in published maps and institutional affiliations.

(i) Open Access This article is licensed under a Creative Commons Attribution 4.0 International License, which permits use, sharing, adaptation, distribution and reproduction in any medium or format, as long as you give appropriate credit to the original author(s) and the source, provide a link to the Creative Commons license, and indicate if changes were made. The images or other third party material in this article are included in the article's Creative Commons license, unless indicated otherwise in a credit line to the material. If material is not included in the article's Creative Commons license and your intended use is not permitted by statutory regulation or exceeds the permitted use, you will need to obtain permission directly from the copyright holder. To view a copy of this license, visit http://creativecommons.org/licenses/by/4.0/.

(c) The Author(s) 2019 